\title{
Pembibitan Jiwa Edupreneurship Pada Guru Madrasah Ibtidaiyah Se Kota Batu Melalui Pelatihan Digital Content Creator
}

\author{
Abdul Bashith ${ }^{1}$, Ali Nasith ${ }^{2}$, Rifa Hidayah ${ }^{3}$ Waluyo Satrio Adji ${ }^{4}$ \\ M. Ali Mashuri ${ }^{5}$ M. Bahrul Ulum ${ }^{6}$ Erdin Putra Pratama ${ }^{7}$ \\ 1,2,7 Jurusan Pendidikan Ilmu Pengetahuan Sosial, UIN Maulana Malik Ibrahim Malang \\ ${ }^{3}$ Jurusan Psikologi, UIN Maulana Malik Ibrahim Malang \\ 4,5,6Jurusan Pendidikan Guru Madrasah Ibtidayah, UIN Maulana Malik Ibrahim Malang \\ Abbash98@pips.uin-malang.ac.id,_Alinasith@gmail.com,rifa_hidayah@psi.uin-malang.ac.id,waluyo.satrio.adji@uin- \\ malang.ac.id
}

\section{Info Artikel \\ Riwayat Artikel: \\ Diterima: Agustus 2021 \\ Direvisi: Agustus 2021 \\ Diterbitkan: September 2021}

\section{Keywords:}

Edupreneurship

Digital content creator,

Madrasah Ibtidaiyah teacher

Batu Town

\begin{abstract}
The purpose of this study was to determine the activities of planning, implementing, observing, and evaluating in nurturing the spirit of edupreneurship in non-permanent teachers at Madrasah Ibtidaiyah in other Batu City through digital content creator training. The method used is PAR (Participatory Action Research). The PAR method involves researchers and communities working together to identify and resolve problems. Activities at this planning stage, namely the preparation of training activity materials. This activity was carried out in the form of a focus group discussion (FGD) involving the chairman of the Batu City KKMI, representatives of teachers, researchers, and resource persons. The agreed FGD results. The action stage is actualized with a training event that is divided into two mirrors. First, making learning videos. Both uploads. Observations, observations that have been made in the training obtained weaknesses and strengths experienced by researchers, coordinators, and teachers both in terms of attitudes and obstacles in training such as facilities and infrastructure. Reflection and evaluation activities are in the form of conveying supporting and inhibiting factors during the training activities and giving appreciation to participants.
\end{abstract}

Copyright (C) 2021 JRCE. All rights reserved.

\section{Korespondensi:}

Waluyo Satrio Adji,

UIN Maulana Malik Ibrahim Malang,

Jl. Gajayana No. 50 Malang, Jawa Timur, Indonesia 65144

waluyo.satrio.adji@uin-malang.ac.id

\section{PENDAHULUAN}

Permasalahan Wabah Covid berdampak pada sektor pendidikan [1] diantaranya berpengaruh kebijakan penggunaan dana BOS untuk menggaji guru honorer, per April terbit Permendikbud Nomor 19 tahun 2020 berisi tata kelola secara teknis pencairan Bantuan Operasional Sekolah atau BOS. Pada aturan ini selama masa darurat kesehatan wabah corona guru dapat digaji dengan pencairan dana BOS secara penuh dengan beberapa syarat [2]. Akan tetapi kebijakan tersebut menurut Ketua IGI hal tersebut tidak tepat karena porsi dana BOS sebagaian perlu juga untuk pengelolaan operasional terkait covid 19 [3]. 
Pada Kota Batu gaji guru tidak tetap tergolong rendah atau selisihnya jauh di bawah Upah Minimum Regional [4]. Hasil observasi dan wawancara gaji guru per bulan 300 ribu, memang mendapat tunjangan atau dari dana BOS tetapi belum tingkat kebutuhan keluarga yang diperlukan. Dana BOS itupun masih harus menunggu pencairan dan kadang tidak tentu alias tidak bisa dijadikan tumpuan berkala.

Kesulitan yang dihadapi guru akibat wadah pendemi covid 19 bukanlah halangan untuk selalu terpuruk dan putus asa, jika mengaji dan mengkaji ayat al Quran surah Al Insyirah ayat 5 dan 6 [5]: Mengaji dari Tafsir Fi Zhilalil Quran karya Sayyid Qutub ditegaskan, "Sesungguhnya kesulitan itu tidak lepas dari kemudahan yang menyertai dan mengiringinya."[6] Isyarat ilmiah yang termaktub dalam ayat tersebut kiranya sebagai harapan dan inspirasi bahwa sebagai manusia yang mengahdapi setiap kesulitasn untuk selalu berikhtiar keluar dari kesuitan diakibatkan oleh wabah covid 19. Oleh karena itu mindset yang perlu diaplikasikan adalah pemikiran dari para wirausaha yaitu memanfaatkan setiap kesulitan sebagai peluang untuk mendapatkan keuntungan.[7]

Salah satu potensi bidang pendidikan adalah pengembangan media pembelajaran, kasusnya selama ini guru menggunakan menyampaikan materi pembelajaran tetapi tidak mengunggah ke media platform seperti youtube atau sudah mengunggah tetapi tampilan tidak menarik untuk dilihat. Padahal peluang pada media platform menjanjikan penambahan pendapatan, jika mengamati para youtubers atau pembuat konten kreator. Asumsinya jika hitungan uang banyak berbanding lurus dengan jumlah penonton video maka guru memiliki siswa atau pencari ilmu yang bersedia menonton. Saat ini ada 55 juta[8] pelajar di Indonesia, jumlah tersebut dapat $1 \%$ saja sudah berpotensi memiliki pendapatan dari google adsense, mnc, dsb.

Saat ini kondisi objek pengabdian terdapat 14 Madrasah Ibtidaiyah di Kota Batu yang terdaftar di EMIS [9]. Madrasah Ibtidaiyah tersebar di beberapa Kota Batu. Potensi jumlah siswa dan guru yang di Madrasah Ibtidaiyah Kota Batu, maka berpeluang untuk mendapatkan pendapatan dari google Adsense, Potensi pendidikan dari guru perlu didesain yang menarik dan diunggah pada platform yang menjanjikan feedback financial, disamping untuk menyebarkan ilmu pengetuan juga untuk keuangan, oleh karena itu pelatihan "digital content creator" memberikan kontribusi yang besar pada pembibitan jiwa kewirausahaan.

\section{METODE PENELITIAN}

Metode yang digunakan adalah PAR (Participatory Action Research). Metode PAR melibatkan para peneliti dan masyarakat yang bekerja bersama untuk mengidentifikasi serta menyelesaikan dan mengubah masalah menjadi lebih baik [10]. Metode ini digunakan untuk tidak membuat masyarakat dampingan sebagai obyek, akan tetapi menjadikan mereka sebagai subyek penelitian [11]. Ada beberapa tahapan dalam penelitian Action Research ini, yaitu sebagai berikut.

1. Plan (Perencanaan). Tahapan ini dilakukan setelah memperhatikan kondisi subyek dampingan, yaitu guru tidak tetap di madrasah Ibtidaiyah Kota Batu dengan menggunakan analisis SWOT.

2. Action (Tindakan). Setelah proses perencanaan dilakukan, guru tidak tetap di madrasah Ibtidaiyah Kota Batu mengimplementasikan rencana yang telah dibuat tersebut dengan dibantu dan difasilitasi oleh tim peneliti.

3. Observe (Pengamatan). Pengamatan dilakukan untuk memperhatikan dan menganalisis keberhasilan, kelemahan, dan kekurangan metode yang digunakan dalam menjalankan kegiatan tersebut. Serta mengetahui faktor pendukung dan penghambat selama kegiatan berlangsung.

4. Reflect (Refleksi). Kegiatan pelatihan pembuatan konten kreatif direfleksikan dan dievaluasi baik kekurangan, kelemahan, dan keberhasilan strategi serta metode selama kegiatan berlangsung. 
Adapun strategi yang digunakan dalam penelitian ini dapat digambarkan sebagai berikut.

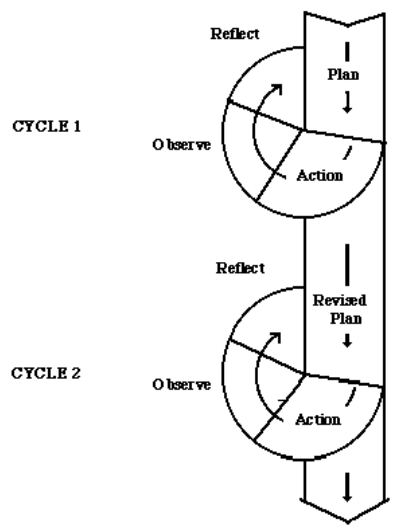

Gambar 1 Model Penelitian Action Research [13], [14]

\section{HASIL DAN PEMBAHASAN}

\subsection{Hasil}

Hasil kegiatan pengabdian dengan metode PAR ini, dijabarkan dalam siklus yang terdiri dari perencanaan (plan), tindakan (action), pengamatan (observe), dan refleksi (reflect). Kegiatan dalam pengabdian pelatihan digital content creator pada Guru Madrasah Ibtidaiyah se-Kota Batu melibatkan beberapa golongan, yaitu guru Madrasah Ibtidaiyah, pelatih/narasumber, Ketua Kelompok Kerja Madrasah Ibtidaiyah (KKMI).

\section{Tahap Perencanaan (Plan)}

Kegiatan pada tahap perencanaan ini, yaitu penyusunan materi kegiatan pelatihan. Kegiatan ini dilaksanakan dalam bentuk focus group discussion (FGD) dengan melibatkan ketua KKMI Kota Batu, perwakilan guru, peneliti, dan narasumber. Kegiatan ini dilakukan setelah memperhatikan kondisi subyek dampingan, yaitu guru madrasah ibtidaiyah di Kota Batu dengan menggunakan analisis SWOT.

SWOT terdiri dari empat aspek yaitu strength, weakness, opportunities, threats. Analisis awal dilakukan dengan mengamati kekuatan kekuatan (strength) didapati guru madrasah memiliki pendukung berupa sarana yang menunjang seperti laptop, handphone berbasis android, sinyal internet yang, materi pembelajaran lengkap dengan perangkat pembelajaran yang tidak asing lagi dengan yang diajarkan di kelas.

Kelemahan (weaknesses) didapati kurangnya pengetahuan dalam memonitisasi channel dan kurang kreatifnya dalam pembuatan video pembelajaran yang kreatif. Hal ini dituturkan oleh guru Madrasah Ibtidaiyah Ihyaul Ulum saudara M. Ilham Zulkarnain, S.Pd bahwa pada masa pandemi ini guru dituntut untuk membuat video pembelajaran untuk diunggah di platform youtube akan tetapi video yang ada seadanya terkesan hanya untuk memenuhi kewajiban semata, jika video dikaji secara subjektif tidak ada kemenarikan dan tidak ada nilai tambah untuk pembuat yaitu guru hal itu dikarenakan pengetahuan tentang platform youtube tidak ada.

Untuk analisis kesempatan (opportunities), dalam diskusi yang dilakukan dengan ketua kelompok kerja KKMI Kota Batu, Bapak Suparsi bahwa kesempatan untuk mendapat nilai tambah dari unggahan di platform youtube sangat besar karena secara kesempatan setiap guru yaitu membuat akun youtube gratis dan daya dukung situasi kondisi adalah sama seperti lebih dari 200 siswa pada setiap sekolah jika digabungkan ke lebih dari 2000 siswa. Jika dikordinasi kurang lebih dapat memberikan solusi khususnya dalam mendapatkan tambahan bagi guru Madrasah Ibtidaiyah.

Pada aspek ancaman (threats), ancaman terhadap masalah kesejahteraan terutama pendapatan memiliki peran sentral pada setiap individu karena berkaitan sambung hidup. Pada era pandemi covid 19 berdampak pada lembaga madrasah swasta dengan guru honorer terutama dalam hal gaji. Perlu pendapatan dari sektor lain, jika tidak terpenuhi maka guru yang mendapat akan mencari di luar bidang keahlian. 


\section{Tahap Tindakan (Action)}

Tersusunnya perencanaan selanjutnya memasuki tahap tindakan (action) yang diaktualisasikan dengan fasilitas dari tim peneliti. Pelaksanaan pelatihan digital content creator dilaksanakan pada tanggal 24 dan 25 mei 2021 secara daring menggunakan aplikasi zoom meeting, dengan didampingi oleh tim peneliti guna kelancaran acara. Berikut poster pelatihan digital content creator untuk guru Madrasah Ibtidaiyah Kota Batu.

Sesuai agenda pelatihan meskipun dilakukan secara daring tetapi tim mempunyai tempat kordinasi yaitu di Madrasah Ibtidaiyah Mifatahul Ulum bertempat di Jalan Munif Kota Batu. Waktu pelatihan sesuai dengan jadwal pukul 10.00-12.00 WIB. Teknisnya pelatihan dilakukan secara daring dan luring, untuk narasumber pelatihan mengundang dua dosen khusus, pertama, Muh. Miftakhurohman, M.Kom dan kedua, Wahyuzi, M.Pd. Narasumber pertama berprofesi sebagai dosen IT di ITN Malang, yang saat ini kuliah di UGM Yogyakarta. Narasumber kedua yaitu dosen UIN Antasari Banjarmasin yang juga youtubers dengan konten

\section{UIN MENGABDI QARYAH THAYYIBAH 2021}
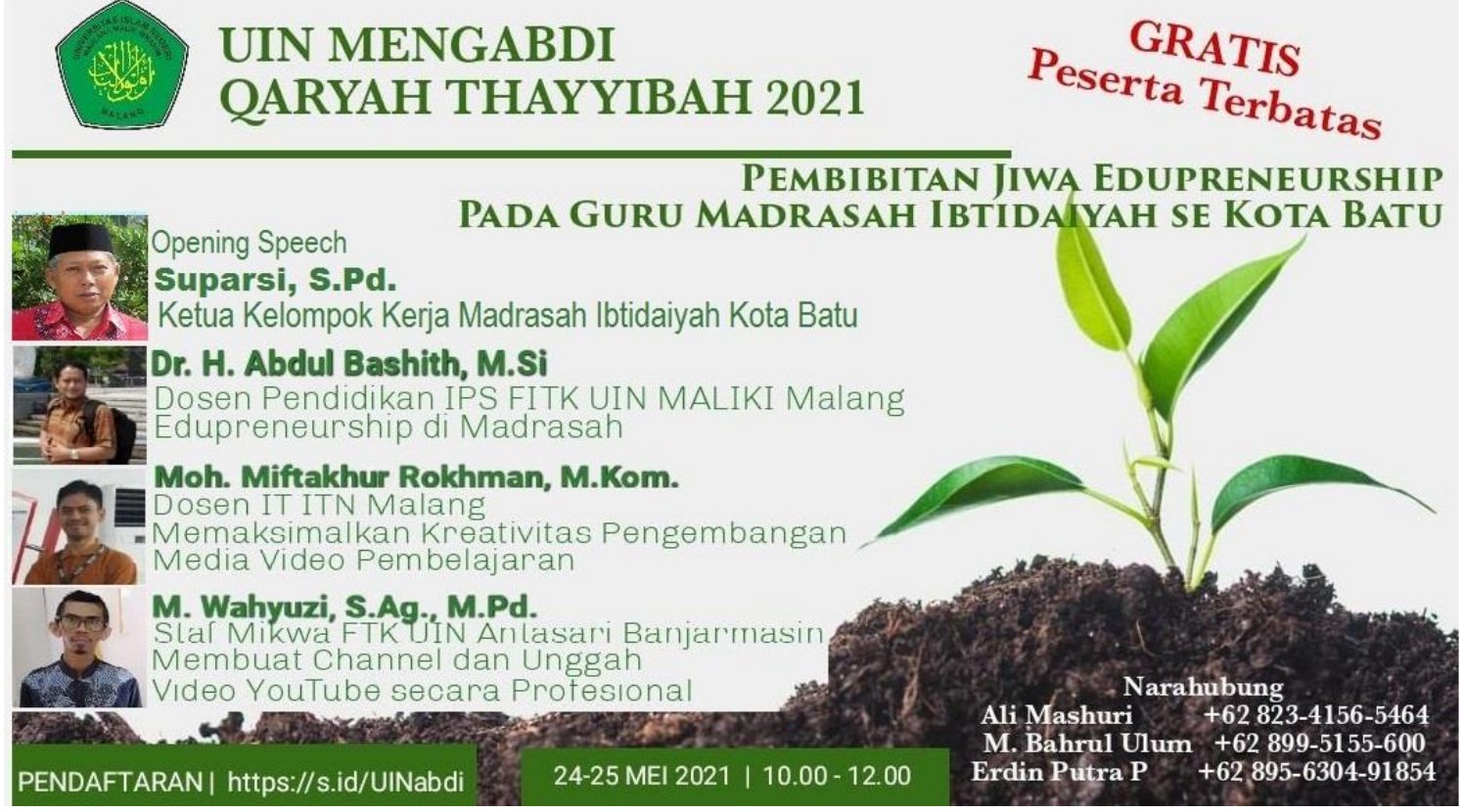

Gambar 2 Poster Pengabdian untuk dibagikan ke Guru Madrasah Ibtidaiyah se Kota Batu

pendidikan yang mempunyai 1000k pengikut dengan jumlah konten 35 video.

Tahapan tindakan (action) ini dibagi menjadi beberapa kegiatan sebagai berikut.

a. Kondisi Subjek Pengabdian oleh Ketua KKMI Kota Batu

Pembukaan pelatihan diawali dengan sambutan oleh Ketua Kelompok Kerja Madrasah Ibtidaiyah Kota Batu yaitu Bapak Suparsi, S.Pd. Pada sambutannya dipaparkan terkait kondisi guru dan Madrasah Ibtidaiyah di Kota Batu khususnya dalam menghadapi wabah pandemi covid 19. Dengan data sesuai dengan pemberitaan di media massa yaitu penuh dengan kesulitan khususnya terkait kesejahteraan.

b. Sosialisasi Pembibitan Jiwa Edupreneurship

Kegiatan sosialisasi ini bertujuan untuk memberikan wawasan kepada guru Madrasah Ibtidaiyah tentang pengabdian lebih lanjut dipaparkan oleh ketua Peneliti yaitu Dr. H. Abdul Bashith, M.Si. terkait tujuan pengabdian masyarakat dengan tema pembibitan jiwa edupreneurship melalui pelatihan digital content creator. Pada latar belakangnya dijelaskan terkait pemberitaan dan hasil observasi pada kondisi guru Madrasah Ibtidaiyah Kota Batu sehingga pengabdian diadakan sebagai respon atau jawaban guna membantu guru Madrasah Ibtidaiyah dalam memberikan jalan guna mengatasi kesulitan hidup khususnya ekonomi.

c. Pelatihan dan Pendampingan digital content creator

Pelatihan dan pendampingan dimulai dengan membuat konten kreatif dalam mengemas materi pembelajaran dengan bentuk akhir yaitu video pembelajaran. Materi pengenalan terkait pentingnya media pembelajaran dalam mengefektifkan kegiatan pembelajaran guna mencapai tujuan pembelajaran yang ditulis dalam Rencana Pelaksanaan Pembelajaran. 
Setelah penyampaian pemahaman media pembelajaran dilanjutkan dengan penyampaian agenda dalam kegiatan pelatihan diantaranya adalah penyiapan materi pembelajaran. Pada tahapan penyiapan materi pembelajaran sudah dikonfirmasi untuk disiapkan peserta yang berasal dari materi yang sudah pernah diajarkan atau minimal materi dalam bentuk power point. Kemudian bagaimana cara merekam video yang selanjutnya sebagai penyempurnaan perlu editing video yang didalamnya ada pengkombinasian video dan power point untuk selanjutnya dikonversi ke video.

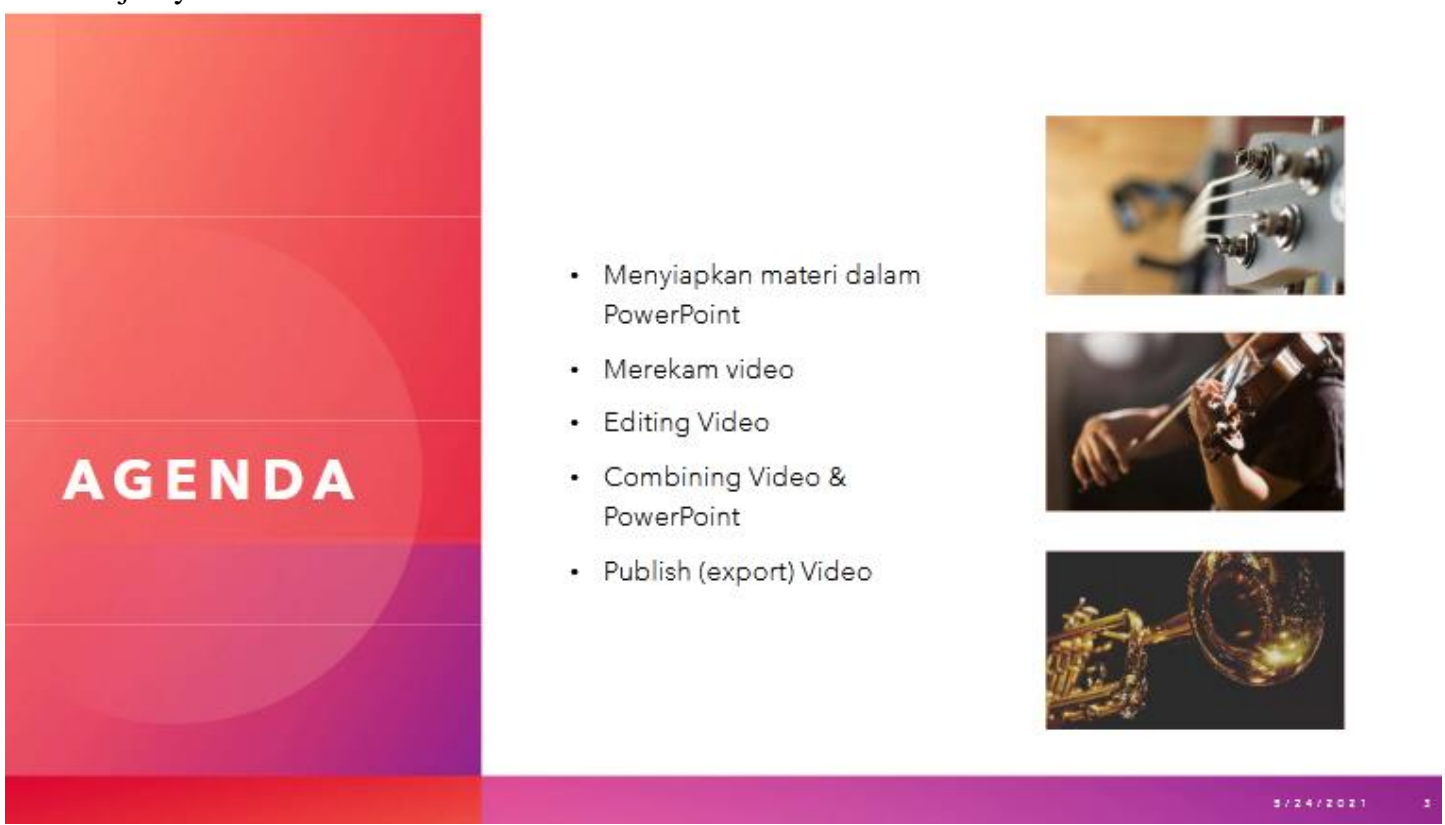

Gambar 3 Susunan Pengabdian Pembuatan Video Pembelajaran Kreatif

Setelah penyampaian narasumber pertama, kemudian dilanjutkan dengan praktik pembuatan yang secara bersama-sama diikuti peserta secara daring. Narasumber kedua adalah bapak Wahyuzi, M.Pd yaitu dosen dan youtubers dari UIN Antasari Banjarmasin. Judul yang diangkat yaitu bagaimana membuat channel dan mengunggah video secara profesional. Pendalaman materi yang perlu diperhatikan sebelum membuat channel hal tersebut dilakukan guna memaksimalkan channel yang dibuat sehingga menarik untuk ditonton penonton nantinya sehingga didapat apresiasi berupa like dan subscribe.

\section{Hal yang Perlu Diperhatikan Sebelum Membuat Channel}

$>$ Topik

$>$ Terget Penonton

$>$ Nama Channel

Branding

$>$ Konten

$>$ Search Engine Optimization

$>$ Sosial Media

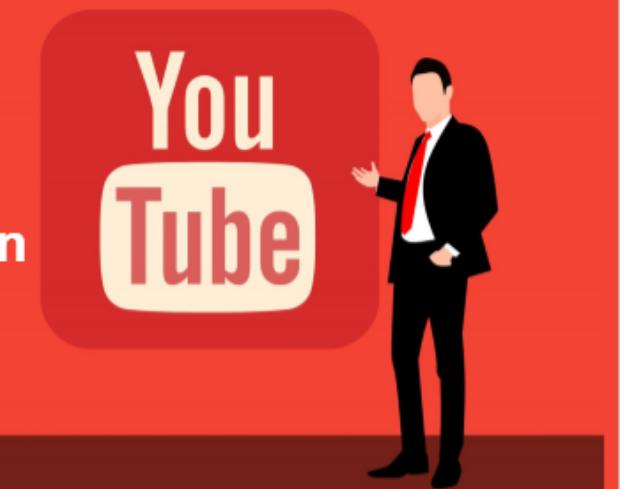

Gambar 4 Kiat sebelum Pembuatan dan Pengunggahan Video Pembelajaran 
Seperti narasumber pertama, narasumber kedua memaksimalkan pelatihan dengan praktik langsung guna pemahaman lebih lanjut dan buah dari pelatihan dapat langsung dihasilkan. Narasumber kedua memberikan penjelasan terkait operasional pada pengunggahan di Youtube.

\section{Tahap Pengamatan (Observe)}

Pengamatan dilaksanakan guna memahami keberhasilan dan kelemahan dari pelatihan digital content creator. Hasil observasi yang telah dilakukan pada pelatihan didapat kelemahan dan kelebihan, lebih lanjut beberpa poin sebagai berikut.

a. Peneliti, kordinator, dan guru bersikap terbuka dalam merumuskan tujuan pelatihan yang akan diselenggaran sehingga peserta tertarik dan praktik bersama.

b. Peserta dan narasumber antusias dengan bentuk saling menanggapi dalam tanya jawab

c. Peserta antusias dalam mengikuti karena alat dan bahan yang disajikan sudah tidak asing dalam pembuatan video pembelajaran.

d. Peserta begitu antusias pada tema kedua karena diberikan wawasan dunia digital yang membuka peluang untuk mendapatkan tambahan pendapatan yang berasal dari unggahan materi pembelajaran. Adapun kelemahan-kelemahan dalam metode dalam pelatihan digital content creator, yaitu sebagai berikut.

a. Peserta yang mengikuti pelatihan hanya sekitar 40 guru, hal ini dikarenakan bulan Mei adalah bulan persiapan untuk melakukan penilaian akhir tahun (PAT) jadi sekolah mengizinkan perwakilan guru Madrasah Ibtidaiyah untuk mengikuti pelatihan.

b. Kondisi sinyal dari peserta dan narasumber yang tidak stabil, menjadikan pelatihan terganggu dengan keterlambatan video dan suara yang terpotong-potong dan tidak jelas sehingga peserta sering bingung untuk mengikuti langkah selanjutnya.

c. Software dan aplikasi terkadang error, karena kondisi pelatihan secara daring menjadikan kendala yang dihadapi peserta tidak teratasi secara tuntas.

\section{Tahap Refleksi (Reflect)}

Kegiatan pelatihan digital content creator dapat direfleksikan dan dievaluasi. Kegiatan evaluasi dilakukan dilapangan pada tanggal 8-9 Juni 2021 di Madrasah Ibtidaiyah Miftahul Ulum. Pada refleksi tersebut disampiakan faktor pendukung dalam kegiatan pelatihan antara lain: 1) kompetensi dan pengalaman narasumber sesuau dibidangnya; 2) modal memiliki akun di youtube; 3) peralatan keras dan lunak mudah di dapatkan sebagai pendukung pembuatan video pembelajaran; dan 4) sudah ada kordinasi kelompok kerja guru madrasah di kota Batu yakni KKMI, hal ini memudahkan dalam perencanaan dan pelaksanaan pelatihan.

Selain itu, faktor penghambat dalam pelatihan, yaitu 1) wabah virus yang merebak menjadikan pelatihan diadakan secara daring 2) merujuk pada no pertama sehingga pendampingan kurang maksimal secara emosional. 3) Jadwal kegiatan Madrasah yang padat menjadikan jumlah peserta hanya di kisaran 40.

\subsection{Diskusi Keilmuan}

Pada Edupreneurship atau kewirausahaan bidang pendidikan dapat dibagi menjadi empat kategori [12] yaitu

a. Inovasi pada sekolah pemerintah atau negeri. Pada pelatihan digital content Creator aspek inovasi pada sekolah dilakukan oleh guru Madrasah Ibtidaiyah melalui pelatihan yang diajarkan berupa bahan atau pengkonversian dari bersifat luring menjadi daring buku teks menjadi sebuah video pembelajaran, meskipun sudah Umum dilakukan oleh beberapa guru yang ada saya umumnya akan tetapi pada pelatihan diberikan sebuah inovasi terkait tentang bagaimana cara mengedit video pembelajaran sesuai dengan tujuan pembelajaran dengan memperhatikan karakteristik siswa media juga teori yang akan diajarkan

b. Mendirikan sekolah swasta, yang mana adalah bagian dari sistem pendidikan formal. Pada poin sekolah latihan diumpamakan pembuatan sebuah akun atau channel YouTube itu sebagai pendirian sebuah sekolah akan diberi sebuah kurikulum yang isinya pembelajaran untuk di tonton oleh

c. Mendirikan organisasi, Pembuatan channel di dalamnya terdapat tata kelola yang baik guna memaksismalkan video yang diunggah.

d. kerjasama lembaga pendidikan negeri-swasta. Pada kerjasama lembaga pendidikan pelatihan sebelumnya dikatakan bahwa sekolah dalam hal ini adalah pembuatan sebuah akun atau channel YouTube dalam hal kerjasama antar lembaga atau antar akun digunakan sebuah teori social network analysis teori hubungan

Pembibitan Jiwa Edupreneurship Pada Guru Madrasah Ibtidaiyah Se Kota Batu Melalui Pelatihan Digital Content Creator (Abdul Bashith) 
sosial dalam lingkup daring yaitu bagaimana menambah subscribe menambah like atau juga cari sebuah komen dari akun akun YouTube yang lain sehingga dapat cari guru Madrasah Ibtidaiyah Kota Batu.

\section{KESIMPULAN}

a. Kegiatan pada tahap perencanaan ini, yaitu penyusunan materi kegiatan pelatihan. Kegiatan ini dilaksanakan dalam bentuk focus group discussion (FGD) dengan melibatkan ketua KKMI Kota Batu, perwakilan guru, peneliti, dan narasumber. Hasil FGD yang telah disepakati, yaitu sosialisasi, muatan materi dalam pelatihan yang meliputi dasar pembuatan konten kreatif dilanjutkan dengan praktik sampai menjadi video, kemudian bagaimana teknik pengunggahan dan promosi secara profesional sehingga berpotensi mendapatkan monetitasi di platform youtube.

b. Tahap tindakan (action) yang diaktualisasikan dengan fasilitas dari tim peneliti. Pelaksanaan pelatihan digital content creator dilaksanakan pada tanggal 24 dan 25 mei 2021 secara daring menggunakan aplikasi zoom meeting. Acara pelatihan dibagi dua cermin. Pertama, pembuatan video pembelajaran. Kedua pengunggahan.

c. Pengamatan dilaksanakan guna memahami keberhasilan dan kelemahan dari pelatihan digital content creator. Hasil observasi yang telah dilakukan pada pelatihan didapat kelemahan dan kelebihanyang dialami oleh peneliti, kordinator, dan guru baik dari segi sikap dan hambatan dalam pelatihan seperti sarana dan prasaran.

d. Kegiatan pelatihan digital content creator dapat direfleksikan dan dievaluasi. Kegiatan evaluasi dilakukan dilapangan pada tanggal 8-9 Juni 2021 di Madrasah Ibtidaiyah Miftahul Ulum Kota Batu. Refleksi dan evaluasi berupa penyampaian faktor pendukung dan penghambat selama kegiatan pelatihan dilaksanakan dan apresiasi kepada peserta.

\section{UCAPAN TERIMAKASIH}

Ucapan terimakasih kepada guru Madrasah Ibtidaiyah se Kota Batu, khususnya kepada Bapak Suparsih, S.Pd. sekaligus Ketua Kelompok Kerja Madrasah Ibtidaiyah Kota Batu.

\section{DAFTAR PUSTAKA}

[1] M. Siahaan, "Dampak Pandemi Covid-19 Terhadap Dunia Pendidikan," J. Kaji. Ilm., vol. 1, no. 1, pp. 73-80, Jul. 2020, doi: 10.31599/jki.v1i1.265.

[2] Kemendikbud, Kementrian Pendidikan dan Kebudayaan Republik Indonesia. Kementrian Pendidikan dan Kebudayaan Republik Indonesia, 2020, pp. 1-3.

[3] A. Yulianto, "IGI Curigai Ada Pasal Titipan di Permendikbud 19/2020 | Republika Online,” Republika, 2020. https://republika.co.id/berita/q8xi85396/igi-curigai-ada-pasal-titipan-di-permendikbud-192020 (accessed Apr. $12,2021)$.

[4] "Gaji Guru Honorer Kota Batu Jauh di Bawah UMR - Nusa Daily.” https://nusadaily.com/regional/gaji-guruhonorer-kota-batu-jauh-di-bawah-umr.html (accessed Apr. 12, 2021).

[5] R. Kementerian Agama, Al-Qur'an Terjemahan. 2007.

[6] S. Quthb, Tafsir Fi Zhilalil Quran. 2003.

[7] R. Lewenussa and H. Suaidy, "Pengaruh Pola Pikir (Mindset) Kewirausahaan Terhadap Motivasi Dan Keterampilan Wirausaha Mahasiswa Program Studi Manajemen Universitas Muhammadiyah Sorong," SENTRALISASI, vol. 8, no. 1, p. 1, Feb. 2019, doi: 10.33506/sl.v8i1.385. 
[8] “Konten Inovatif Bikin Belajar Online Bakal Makin Diminati,” Indozone.id, 2020. https://www.indozone.id/news/XxsryP/konten-inovatif-bikin-belajar-online-bakal-makin-diminati/read-all (accessed Apr. 12, 2021).

[9] E. Pendis, "EMIS | Dashboard | Pendis Kemenag," Kementrian Agama, 2021. http://emispendis.kemenag.go.id/dashboard/?content=madrasah\&action=detail\&prov=35\&kab=KOTA BATU (accessed Apr. 12, 2021).

[10] S. Kindon, R. Pain, and M. Kesby, Participatory Action Research Approaches and Methods: Connecting People, Participation and Place. New York: Routledge, 2007.

[11] C. MacDonald, "Understanding Participatory Action Research," Can. J. Action Res., vol. 13, no. 2, pp. 34-50, 2012.

[12] B. Tamam and A. Muadin, "IMPLEMENTASI EDUPREUNEURSHIP DALAM PEMBENTUKAN KARAKTER SEKOLAH UNGGUL,” Ulumuna J. Stud. Keislam., vol. 5, no. 1, pp. 13-21, 2019, doi: 10.36420/ju.v5i1.3521.

[13] A. B. Amaya and N. Yeates, "Participatory Action Research: New Uses, New Contexts, New Challenges," ESRC-DfID Conf. Poverty Reduct., p. 23, 2014.

[14] B. Kartowagiran, "Dasar-Dasar Penelitian Tindakan,” p. 22, 2005. 